\title{
A Neglected Disease: Scabies a Retrospective Study On Children
}

\author{
İhmal Edilen Bir Hastalık: Uyuz, Çocuklar Üzerine Retrospektif Bir \\ Çalışma
}

\author{
Sinan OZCELIK
}

Department of Skin and Venereal Diseases, Balıkesir University School of Medicine, Balikesir, Turkey

\begin{abstract}
Objective: Scabies is one of the diseases that can be minimized with preventive health measures. Accurate diagnosis of scabies is important for both patient and public health. Diagnosis of scabies in children can be challenging, since the clinical features in children may differ from those of adults. The aim of the present study was to investigate the demographic and clinical characteristics of the patients with scabies in childhood.

Material and Methods: The patients aged 0-18 years, who were diagnosed with scabies and presented to the dermatology outpatient clinic of our hospital, were included in the study. The demographic characteristics of the patients, time of admission, duration of symptoms, family history, the presence of specific lesions, and any lesions on the scalp, face, palmoplantar region, laboratory findings (if any), previous hospital admissions, treatment, and complications were recorded retrospectively.

Results: Fifty six of the 104 patients were male (53.8\%) and 48 were female (46.2\%). The mean age was $5.82 \pm 5.21$ years. The mean duration of symptoms was $2.41 \pm 2.24$ months. Eighty four patients had a family history of scabies (80.7\%). Seventy patients (67.3\%) had at least one specific lesion of scabies. Atypical sites of involvement were palmoplantar region (33.6\%), head (6.7\%), and face (2.8\%). The most commonly used diagnostic tool was dermatoscopy. Forty-one patients were treated with permethrin $5 \%$ lotion (39.4\%) and 63 with sulfur ointment (60.5\%). Of all admissions to the hospital, admissions were highest in fall (40.4\%), followed by winter (30.8\%), summer (18.2\%), and spring (10.6\%). Eight patients developed complications (7.6\%), including 5 with impetigo and 3 with paronychia.

Conclusion: Scabies is an important health issue that can be treated with an accurate and prompt diagnosis. It was observed that the head, face, palms, and soles often are involved in infants and very young children, unlike adults. Therefore, clinicians should consider the clinical differences between adults and children in the management of scabies in children. Also, dermatoscopy is a practical and effective diagnostic tool especially in infants and young children with scabies.
\end{abstract}

Key Words: Childhood, Dermatoscopy, Scabies

\section{Öz}

Amaç: Skabiyes, koruyucu sağlık önlemleri ile azaltılabilecek hastalıklardandır. Skabiyesin doğru teşhisi, hem hasta hem de halk sağlığı için önemlidir. Skabiyesin çocuklardaki klinik özellikleri yetişkinlerden farklı olabileceğinden çocuklarda skabiyes tanısı zor olabilir. Bu çalışma ile çocukluk çağında saptanan skabiyes olgularının demografik ve klinik özelliklerin araştırılması amaçlandı.

Gereç ve Yöntemler: Hastanemiz dermatoloji polikliniklerine başvuran, 0-18 yaş arası skabiyes tanısı alan hastalar çalışmaya dahil edildi. Hastaların demografik özellikleri, başvuru zamanı, semptomların süresi, aile hikayesi, spesifik lezyon varlığı, saçı deri, yüz, palmoplantar bölgede lezyon varlığı, varsa laboratuar bulguları, önceki hastane başvurusu, tedavi ve komplikasyon gelişimi retrospektif olarak kaydedildi.

(1)

OZCELIKS :0000-0003-2115-276X
Conflict of Interest / Çıkar Çatışması: On behalf of all authors, the corresponding author states that there is no conflict of interest.

Ethics Committee Approval / Etik Kurul Onayr: Approval for the study was obtained from Erzincan University, Clinical Research Ethics Committee (Decision number 3/303; 04.04.2017).

Contribution of the Authors / Yazarların katkısı: OZCELIK S: Constructing the hypothesis or idea of research and/or article, Planning methodology to reach the Conclusions, Organizing, supervising the course of progress and taking the responsibility of the research/study, Taking responsibility in patient follow-up, collection of relevant biological materials, data management and reporting, execution of the experiments, Taking responsibility in logical interpretation and conclusion of the results, Taking responsibility in necessary literature review for the study, Taking responsibility in the writing of the whole or important parts of the study, Reviewing the article before submission scientifically besides spelling and grammar

How to cite / Atıf yazım şekli : Ozcelik S. A Neglected Disease: Scabies a Retrospective Study On Children. Turkish J Pediatr Dis 2022;16:121-126.
Correspondence Address / Yazıșma Adresi:

Sinan OZCELIK

Department of Skin and Venereal Diseases,

Balıkesir University School of Medicine, Balikesir, Turkey

E-posta: sinozc@gmail.com
Received / Geliş tarihi : : 12.01.2021 Accepted / Kabul tarihi : 31.03.2021

Online published

Elektronik yayın tarihi

DOI: $10.12956 /$ tchd.859692 
Bulgular: Yüz dört hastanın 56'si erkek (\%53.8), 48'i kızdı (\%46.2). Yaş ortalaması 5.82 \pm 5.21 yıldı. Hastaların ortalama semptom süresi

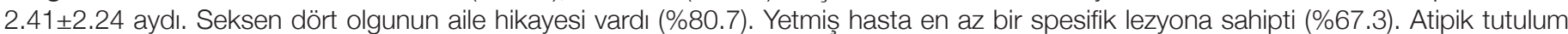
bölgeleri palmoplantar bölge (\%33.6), baș (\%6.7) ve yüz (\%2.8)'di. En sık kullanılan tanısal araç dermatoskopiydi. Kırk bir olgu permetrin \%5 losyon (\%39.4) ile 63 olgu sülfürlü merhemle (\%60.5) tedavi edildi. Hastaneye yapılan başvuruların en yüksek olduğu dönem sonbahar (\%40.4), ardından kış (\%30.8), yaz (\%18.2) ve ilkbahardı (\%10.6). Beşi impetigo ve 3'ü paronişi olmak üzere 8 hastada komplikasyon (\%7.6) gelişti.

Sonuç: Skabiyes, doğru ve hızlı bir tanı ile tedavi edilebilen önemli bir sağlık sorunudur. Yetişkinlerin aksine baş, yüz, avuç içi ve ayak tabanlarının sıklıkla bebeklerde ve çok küçük çocuklarda tutulduğu görülmüştür. Klinisyenler, çocuklarda skabiyesin yönetiminde erişkinler ve çocuklar arasındaki klinik farklılıkları dikkate almalıdır. Ayrıca dermatoskopi özellikle skabiyesli bebekler ve küçük çocuklarda pratik ve etkili bir tanı aracıdır.

Anahtar Sözcükler: Çocukluk çağı, Skabiyes, Dermatoskopi

\section{INTRODUCTION}

Scabies is a contagious infestation of the skin caused by Sarcoptes scabiei var. hominis. The transmission of scabies can occur via two routes: primarily direct contact with an infested person or less commonly by contact with articles such as bedclothes, towels used by an infested person. Scabies can spread rapidly in crowded living conditions such as child care facilities, nursing homes, prisons, refugee camps. It seems that the incidence of scabies has been increasing significantly in recent years. Many physicians, especially dermatologists, pediatricians and family physicians, frequently encounter scabies in their daily clinical practice. The prevalence and clinical characteristics of scabies in children are different from adults. It is said that children are an underestimated source of scabies. The prevalence of scabies tends to be higher in children than in adults, and children are more likely to develop scabies with more numerous mites (1). Therefore, it was planned to attract attention to scabies as a neglected disease with this study and aimed to investigate the demographic and clinical characteristics of the patients with scabies in childhood.

\section{MATERIAL and METHODS}

The patients aged 0-18 years who were diagnosed with scabies and presented to the dermatology outpatient clinic of our hospital in 2015 and 2016 years, were included in the study. The demographic characteristics of the patients, time of admission, duration of symptoms, family history, the presence of specific lesions, and any lesions on the scalp, face, palmoplantar region, laboratory findings (eosinophilia or serum total lgE elevation), previous hospital admissions, treatment, and complications were recorded retrospectively. It was considered as family history for her/him in case of at least one person other than herself/himself had scabies among household members. The diagnosis of scabies was made on the basis of severe itching, typical history and specific clinical findings. It was considered as the presence of specific lesion in case of a patient had any specific clinical findings such as burrow/silion and vesicle or any typical lesions (papules or nodules) on male genitalia (Figure 1, 2). Unlike adults, scabies usually involves

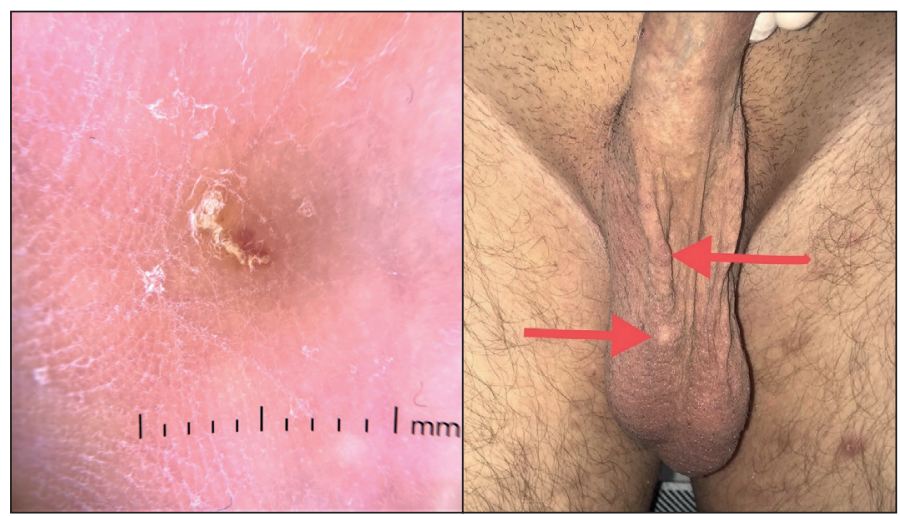

Figure 1: Burrow observed on Figure 2: Scabies papules on the the palm by dermatoscopy at X10 scrotum in a 16-year-old case. magnification.

the head, face, palms, and soles in infants and young children. In this regard, the presence of lesions on these areas was also recorded. Approval for the study was obtained from local ethics committee (Decision number 3/303; 04.04.2017).

\section{Statistical Analysis:}

Statistical analyses were conducted using STATA (version 13, StataCorp LLC College Station, Texas, USA) program. Data obtained by counting are expressed as numbers and percentages, and data obtained by measurement are expressed as median and minimum and maximum values.

\section{RESULTS}

Fifty six of the 104 patients were male (53.8\%) and 48 were female (46.2\%). The mean age was 5.82 \pm 5.21 (median 4, minimum 0.15 , maximum 17) years. The mean age of the girls was $6.08 \pm 5.43$ (median 5, minimum 0.15, maximum 17) and $5.59 \pm 5.05$ (median 4, minimum 0.2, maximum 17) for the boys. The mean duration of symptoms was 2.41 2.24 (median 2, minimum 0.2, maximum 12) months. Sixty patients (57.6\%) had previously presented to a hospital and received treatment for scabies. The mean duration of symptoms was $3.49 \pm 2.42$ (median 3, minimum 1, maximum 12) in patients who had previously presented to another hospital, and $0.95 \pm 0.48$ (median 1, minimum 0.2, maximum 2) months for those who 
Table I: Characteristics of the patients.

\begin{tabular}{|l|c|c|c|}
\hline & Median & Minimum & Maximum \\
\hline Age (year) & 4 & 0.15 & 17 \\
Girls & 5 & 0.15 & 17 \\
Boys & 4 & 0.2 & 17 \\
\hline Mean age of infants and young chidren & 1 & 0.15 & 6 \\
\hline Duration of symptoms (month) & 2 & 0.2 & 12 \\
Patients received a previous treatment & 3 & 1 & 12 \\
\hline Patients without any previous treatment & 1 & 0.2 & 2 \\
\hline Serum eosinophil count* $\left(/ \mathrm{mm}^{3}\right)$ & 750 & 500 & 1400 \\
\hline
\end{tabular}

* for those whose lesions were also on the face, scalp, palms, and soles, **for 10 patients

Table II: Characteristics of the patients according to gender.

\begin{tabular}{|l|c|c|c|}
\hline & Female (n) & Male (n) & Total (n) \\
\hline Patients & $48(46.2 \%)$ & $56(53.8 \%)$ & $104(100)$ \\
\hline Mean of age \pm SD * (year) & $6.08 \pm 5.43$ & $5.59 \pm 5.05$ & $5.82 \pm 5.21$ \\
\hline Mean duration of symptoms \pm SD (month) & $2.31 \pm 1.95$ & $2.51 \pm 2.48$ & $2.41 \pm 2.24$ \\
\hline Family history & 38 & 46 & 84 \\
\hline Presence of specific lesion & 33 & 37 & 70 \\
\hline Previous treatment & 27 & 33 & 60 \\
\hline Head & 3 & 4 & 7 \\
\hline Face & 1 & 2 & 3 \\
\hline Palmoplantar region & 16 & 19 & 35 \\
\hline Treatment (P-S) ${ }^{*}$ & $23-25$ & $18-38$ & $41-63$ \\
\hline Complication & 2 & 6 & 8 \\
\hline
\end{tabular}

*Standard deviation, **(permethrin - sulfur ointment)

were first presented to our hospital. Eighty four patients had family history of scabies (80.7\%).

Seventy patients (67.3\%) had at least one specific lesion of scabies. Of the locations for lesions, the palmoplantar region (33.6\%) were mostly involved, followed by the head (6.7\%), and the face (2.8\%). According to the 2020 International Alliance for Scabies Control Consensus criteria (A-Confirmed, B-Clinical, and C-Suspected Scabies); 70 patients diagnosed with scabies on level $\mathrm{B}$ and 44 on level $\mathrm{C}$ were detected. Forty-one patients were treated with permethrin 5\% lotion $(39.4 \%)$ and 63 with sulfur ointment $(60.5 \%)$. The mean eosinophil count was $770 \pm 283$ (median 750, minimum 500, maximum 1400) in mm3 of 10 patients, whose blood tests were performed. Serum total IgE levels of these cases were normal $(\leq 100 \mathrm{IU} / \mathrm{mL})$. Of all admissions to the hospital, admissions were highest in fall (40.4\%), followed by winter (30.8\%), summer (18.2\%), and spring (10.6\%). Eight patients developed complications (7.6\%), including 5 with impetigo and 3 with paronychia (Table I, II).

\section{DISCUSSION}

Scabies affects approximately 300 million people around the world each year (2). Scabies, which affect people of all ages, races, and social classes, can spread easily in crowded living conditions such as nursing homes, refugee camps, and schools. In 2017, scabies was included as Neglected Tropical Diseases by the World Health Organization (3). However, it is difficult to quantify the burden of scabies, because scabies is not a notifiable disease in our country and has considerable diagnostic issues that may cause over- or under-diagnosis of scabies.

In the literature, the incidence of scabies ranges from 0.2 to $71 \%$ (4). In recent years, the increasing incidence of scabies is remarkable in our country. While the incidence of scabies in the 1980s and 1990s ranged between 2.8-8.1\% in the studies reported from Turkey, it was not reported higher than $1 \%$ by any studies in Turkey from 2000 to 2018 (5). In a recent study reported that an outbreak of scabies occurred in Turkey in 2018 and 2019 (5). Beside, the incidence of scabies varies in different ages according to the socio-economic status of the country. In low-income countries, the incidence of scabies in children is higher than in adults $(6,7)$. The incidence of scabies in children in tropical countries is $5-10 \%$ according to the World Health Organization (4). However, scabies in developed countries is equally seen in all age groups (8). In our country, Çetinkaya et al. (9) reported that scabies was more common in patients aged 25-44 years. Turan et al.(10) found that scabies was more common in young adults (15-44 ages) (10). From another study from Turkey reported that scabies tends to shift 
to younger ages from 2013 to 2018 (11). No difference was observed in the distribution of scabies prevalence according to different ages from 2014 to 2019 in a recent multicentre study conducted in distinct regions of Turkey (12). In our study, the incidence of scabies was $1 \%$, consistent with the rate in the years mentioned above. It can be said that Turkey is in a place between developed countries where scabies is equally seen in all age groups, and underdeveloped countries where scabies is more prevalent in children than in adults.

Considering the gender distribution of patients, a slight male predominance was observed in the present study (Table II). In the literature, there were both female and male dominance observed in various studies investigating scabies (10-12). The population and geographical differences in the studies may explain the contradictory results.

The duration between symptom onset and hospital presentation may vary depending on the severity of the disease. Although there is limited data on this issue in the literature, one study reported that this duration was 98 days in one case (13). The mean duration of symptoms in the present study was 10 weeks (2.41 months). One of the reasons for the long duration may be more than half of our cases $(57.6 \%)$ had a history of previous hospital presentation. Another reason may be the diagnostic issues in children with scabies (especially atypical presentation). There may be also other reasons such as treatment failure, allergic contact dermatitis due to treatment, cross-reactivity between ordinary household mites and Sarcoptes scabiei var. hominis, delusional parasitosis, and secondary infection.

The diagnosis of scabies is usually made based upon typical history and clinical findings. The presence of household members having itching raises suspicion of scabies and supports the diagnosis of scabies (6). Eighty four patients $(80.7 \%)$ had family history of scabies in this study. A history of itching in the same household members should raise suspicion, but is not mandatory for the diagnosis of scabies.

The distribution of lesions in scabies differs in adults and children. Scabies in adults has lesions in a typical distribution involving the webbed spaces of the fingers, flexor surfaces of the wrists, extensor surfaces of the extremities, axillae, beltline, areolae in females, and scrotum in males $(6,14)$. Unlike adults, scabies usually involves the head, face, palms, and soles in infants and young children (6). Lesions are often observed in a more generalized pattern including the head, face, palms, and soles in children less than two years of age (15). Similarly, in the present study infants and very young children (with a mean age of 1.59 years) had lesions on these parts of the body.

Burrows (sillion/tunnel) is a specific sign and caused by the moving scabies mite. They appear as serpiginous, grayish or skin-colored, thin, thread-like elevations on the skin surface, ranging from $0.1-1 \mathrm{~cm}$ long $(6,14)$. A pearl-like vesicle (vesicle perle) can sometimes be seen at the end of the tunnels (14).
However, it is not always possible to see specific lesions in patients with scabies. It is difficult to discriminate tunnels among vesicular and eczematous lesions of scabies in children, particularly infants. Therefore, only visually examining may not be distinctive enough to diagnose scabies in infants. A dermoscopic study of scabies in children found that there was a significant difference on comparing the number of children diagnosed with scabies with naked eye and dermoscopic examination (16). The scabies burrows in 70 patients in the present study were observed using dermatoscopy (Figure 1). Considering the challenges of detecting specific lesions in infants and young children, dermatoscopy is an efficient and sensitive tool for diagnosing scabies $(16,17)$.

It is stated that no seasonal trend in incidence in tropical countries where scabies is prevalent. However, seasonal changes may affect the incidence of scabies in some countries. It was observed that most of the patients in this study presented in fall and winter (71.2\%). A study investigating the seasonality trends of scabies has reported that the incidence of scabies was higher during colder seasons (18). A recent epidemiological study in Turkey also found that patients with scabies increased in fall (10). It can be easily said that the incidence of scabies increases in colder seasons when the increased person-toperson contact and overcrowding occur.

Increased blood eosinophil counts are known to be an expected finding of parasitic infections. However, it is stated that eosinophilia is not common in classic scabies (19). Peripheral eosinophilia has been reported, particularly in other clinical variants of scabies such as crusted or nodular scabies (19). Although blood tests are generally not necessary for the diagnosis of scabies, they were performed in a small number of patients with a mean eosinophil count of $770 / \mathrm{mm} 3$ in the present study (Table I). We had not encountered any studies that focuses on eosinophilia in scabies. So, we could not compare any data due to the lack of data in both our study and the literature.

There are many scabicidal agents (eg permethrin, phenothrin, sulfur, benzyl benzoate, crotamiton, ivermectin, malathion) used in the treatment of scabies (6). There are only topical permethrin and sulfur ointment available in our country. Permethrin is recommended as the first treatment option in the treatment of scabies in many guidelines (20). Although permethrin can be used in infants over 2 months of age, physicians need to be vigilant in the risk of causing toxicity in infants between 2-12 months $(6,21)$. Sulfur ointments has been used in the treatment of scabies for a long time. Although it is recommended as the second treatment option in the European guidelines, sulfur ointments is the first agent to be used in permethrin-resistant cases due to the limited number of anti-scabietic drugs in our country (22). It was observed that most of the patients in this study were treated with sulfur ointment (60.5\%). It is noteworthy that the patients who received treatment with sulfur ointments 
were infants and very young children. It is understood that sulfur ointments were preferred in order to avoid a possible toxicity issue that permethrin may cause in infants and some young children.

Sixty patients (57.6\%) had previously presented to a hospital and received treatment for scabies. In a way, it can be said that the scabies treatments of these patients were failed. Improper and inadequate application, reinfestation and drug resistance are the common reasons of treatment failure. It was found that the major cause of treatment failure in this study was patient non-adherence. It was observed that unfortunately some patients applied the treatment improperly, and mostly the same household members did not apply the treatment. All household members should be treated at the same time as the infested person. Unfortunately, "the non-compliant attitude of same household members" is an incident that most physicians are familiar with hearing from a scabies patient in her/his daily clinical practice. Therefore, one of the most important issues in the success of scabies treatment is the patient's compliance. Physicians should explain in detail how to apply the treatment to each patient. Otherwise, it is not possible to prevent reinfestation and the spread of the disease.

Scabies may be complicated by impetigo, ecthyma, paronychia, furuncle, residual eczematous dermatitis, and rarely generalized urticaria (6). In this study, 8 patients developed complications (impetigo and paronychia) and recovered with appropriate treatments. In a systematic review, impetigo was common, particularly in children with scabies (23). A study investigating scabies outbreak among school children reported that nearly $10 \%$ of the patients developed pyoderma (24). Although complications of scabies are rare, sometimes it can lead to serious health issues such as septicemia, chronic kidney disease, and rheumatic heart disease (23). Therefore, scabies is a preventable disease with serious complications that should not be neglected in children.

Thereare somelimitations in the present study. The main limitation of this study is a single-center study having a retrospective design. We could not compare the data, particularly the incidence of scabies, between years since this study has data on scabies in only 2015 and 2016 years. Although our study encompassed the whole province, it included only patients who presented to the dermatology outpatient clinic. Data from other institutions such as primary care health centers were not included. Besides, socioeconomic status, living conditions, number of misdiagnosis in previous hospital presentations and errors in the applications of treatment were not evaluated.

\section{CONCLUSION}

Scabies is a parasitic skin infestation that can be treated with an accurate and prompt diagnosis. It was observed that the head, face, palms, and soles often are involved in infants and very young children, unlike adults. Children are more likely to develop scabies with atypical presentation than adults. Therefore, clinicians should consider the clinical differences between adults and children in the management of scabies. Dermatoscopy is a practical and effective diagnostic tool especially in infants and young children with scabies.

\section{REFERENCES}

1. Ariza L, Walter B, Worth C, Brockmann S, Weber ML, Feldmeier H. Investigation of a scabies outbreak in a kindergarten in Constance, Germany. Eur J Clin Microbiol Infect Dis 2013;32:373-80.

2. Hicks MI, Elston DM. Scabies. Dermatologic Therapy 2009;22:27992.

3. Engelman D, Cantey PT, Marks M, Solomon AW, Chang AY, Chosidow $\mathrm{O}$, et al. The public health control of scabies: priorities for research and action. Lancet (London, England) 2019;394:8192.

4. World Health Organization. Neglected tropical diseases: Scabies 2020.

5. Baykal C, Atci T, Kutlay A, Baykut B, Türkoğlu Z. Scabies outbreak in Turkey in 2018-2019. Journal of the European Academy of Dermatology and Venereology : JEADV 2021.

6. Thomas C, Coates SJ, Engelman D, Chosidow O, Chang AY. Ectoparasites: Scabies. J o Am Acad Dermatol 2020;82:533-48.

7. Sardana K, Mahajan S, Sarkar R, Mendiratta V, Bhushan P, Koranne $\mathrm{RV}$, et al. The spectrum of skin disease among Indian children. Pediatric Dermatol 2009;26:6-13.

8. Hay RJ, Steer AC, Engelman D, Walton S. Scabies in the developing world--its prevalence, complications, and management. Clin Microbiol Infect 2012;18:313-23.

9. Çetinkaya Ü, Şahin S, Ulutabanca R. The Epidemiology of Scabies and Pediculosis in Kayseri. Turkiye Parazitol Derg 2018;42:134-7.

10. Turan Ç, Metin N, Utlu Z. Epidemiological Evaluation of Scabies Cases Encountered in the Last Three Years as a Tertiary Health Center. Turkiye Parazitol Derg 2020;44:77-82.

11. Aktaş $H$, Cebecik $A$. Changes in Incidence and Age Distribution of Scabies: A Retrospective Cohort Study in A Tertiary Hospital. Arch Clin Exp Med 2019;4:21-4.

12. Özden MG, Ertürk K, Kartal SP, Yayli S, Göktay F, Doğramacı CA, et al. An extraordinary outbreak of scabies in Turkey. J Eur Acad Dermatol Venereol 2020;34:e818-e20.

13. Wilson MM, Philpott CD , Breer WA. Atypical presentation of scabies among nursing home residents. J Gerontol A Biol Sci Med Sci 2001;56:M424-7.

14. Chosidow O. Scabies and pediculosis. Lancet (London, England) 2000;355:819-26.

15. Engelman D, Yoshizumi J, Hay RJ, Osti M, Micali G, Norton S, et al. The 2020 International Alliance for the Control of Scabies Consensus Criteria for the Diagnosis of Scabies. $\mathrm{Br} \mathrm{J}$ Dermatol 2020; 183:808-20.

16. Srinivas S, Herakal K, Murthy S, Suryanarayan S. Dermoscopic study of scabies in children. Indian J Paediatr Dermatol 2019;20:4651.

17. Walter B, Heukelbach J, Fengler G, Worth C, Hengge U, Feldmeier H. Comparison of dermoscopy, skin scraping, and the adhesive 
tape test for the diagnosis of scabies in a resource-poor setting. Arch Dermatol 2011;147:468-73.

18. Mimouni D, Ankol OE, Davidovitch N, Gdalevich M, Zangvil E, Grotto I. Seasonality trends of scabies in a young adult population: a 20-year follow-up. Br J Dermatol 2003;149:157-9.

19. Sluzevich JC, Sheth AP, Lucky AW. Persistent eosinophilia as a presenting sign of scabies in patients with disorders of keratinization. Arch Dermatol 2007;143:670-3.

20. Sunderkötter C, Feldmeier H, Fölster-Holst R, Geisel B, KlinkeRehbein S, Nast $A$, et al. S1 guidelines on the diagnosis and treatment of scabies-short version. J Dtsch Dermatol Ges 2016;14:1155-67.
21. Porto I. Antiparasitic drugs and lactation: focus on anthelmintics, scabicides, and pediculicides. J Hum Lact 2003;19:421-5.

22. Salavastru CM, Chosidow O, Boffa MJ, Janier M, Tiplica GS. European guideline for the management of scabies. J Eur Acad Dermatol Venereol 2017;31:1248-53.

23. Romani L, Steer AC, Whitfeld MJ, Kaldor JM. Prevalence of scabies and impetigo worldwide: a systematic review. Lancet Infect Dis 2015;15:960-7.

24. Kaburi BB, Ameme DK, Adu-Asumah G, Dadzie D, Tender EK, Addeh SV, et al. Outbreak of scabies among preschool children, Accra, Ghana, 2017. BMC Public Health 2019;19:746. 